\title{
SEMIOTIKA STRUKTURALISME SAUSSURE
}

\author{
Fajriannoor Fanani \\ (carbudit@yahoo.com) \\ (Dosen Ilmu Komunikasi Universitas Semarang)
}

\begin{abstract}
Ferdinand de Saussure is widely known as one of the prominent contributor to the theories of sign and language in semiotic. His theory in semiotic create a mark in the history of semiology. His semiotic was also known as one of the foundation of structuralism that growth in France. Structuralism, later become a movement that widespread not only in the field of linguistic but to the field of humanities and social sciences in general. How his semiotic works and how his view on structuralism applied in world of sign and language are interesting object. This writing try to overview all this in a simple and understandable way.
\end{abstract}

Kata Kunci : Semiotik, Strukturalisme, tanda

\section{PENDAHULUAN}

Ferdinand de Saussure dikenal sebagai bapak dari Semiotica/Semiology serta salah satu teoritisi terpenting dalam ilmu linguistik. Selain itu Semiotika Saussure juga menjadi salah satu pencetus awal dari gerakan strukturalisme yang lahir di Perancis pada awal abad ke 20. Strukturalisme yang berawal dari ilmu linguistik ini kemudian dikembangkan juga ke ilmu-ilmu lainnya seperti Sosiologi, Psikologi, Anthropologi, dll. Melihat besarnya pengaruh Semiotik Saussure ini maka menarik sekali untuk membahas Semiotika Saussure dan melihat akar strukturalisme dalam semiotika tersebut.

\section{A. TANDA YANG ARBITRER}

Bayangkan donut yang anda makan sebenarnya tidaklah manis, gurih, dan lezat. Bukan karena donut tersebut dibuat oleh seorang yang tidak ahli, tetapi karena seluruh rasa manis, gurih, dan lezat tersebut ternyata hanyalah sensasi di otak yang distimuli oleh donut tersebut.
Bayangkan anda memakan sepotong kayu dan otak anda salah menerka bahwa itu adalah donut, sehingga sensasi rasa yang diberikan bukanlah rasa sepotong kayu, tetapi malah rasa donut yang manis, gurih, dan lezat. Sama dengan kasus donut ini, anda pastinya juga sering mengalami apa yang sering disebut sebagai miss understanding. Suatu saat teman anda meminta anda berkunjung kerumahnya, ia mendeskripsikan rumahnya sebagai rumah dengan dua jendela, satu pintu, dan sebuah parabola. Butuh waktu lama untuk menemukan rumah tersebut karena ternyata deskripsi yang ada dalam benak anda berbeda dengan kenyataannya.

\section{Gambar 1}

Perbedaan antara Persepsi dan Realita Mengenai Gambaran Rumah

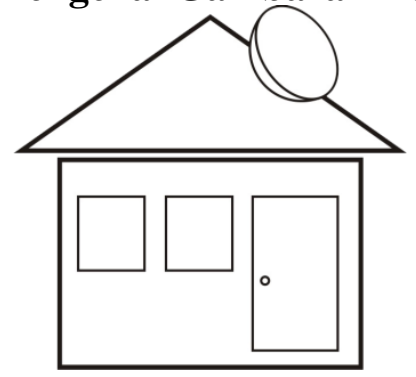


Bayangan anda mengenai deskripsi

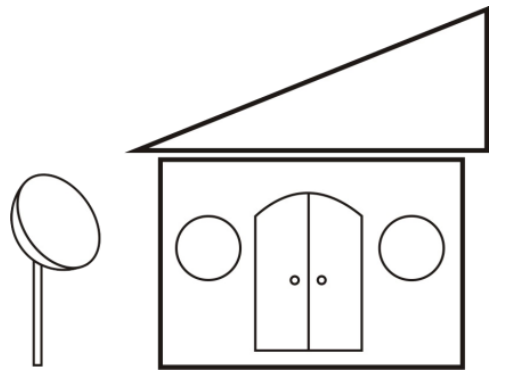

Rumah teman anda sebenarnya rumah teman anda

Hal semacam inilah yang dipikirkan oleh Ferdinand de Saussure saat melihat berbagai tanda. Baginya tanda tersebut hanya bisa merepresentasikan sesuatu apabila si pembaca tanda memiliki pengalaman atas representasi tersebut. Sebuah kata "Indonesia" dapat bermakna kepulauan tropis, merah putih, beragam suku bangsa, dll bagi banyak orang-orang Indonesia. Akan tetapi kata yang sama dalam aksara yang berbeda seperti, "Индонесиа" dapat tidak berarti apapun bagi sebagian orang Indonesia yang tidak dapat membaca tulisan tersebut.

Tabel 1

Kata Indonesia Menurut Beberapa Aksara

\begin{tabular}{|l|l|}
\hline Aksara & \multicolumn{1}{|c|}{ Tulisan } \\
\hline Alfabet & Indonesia \\
\hline Cyrillic & Индонезия \\
\hline $\begin{array}{l}\text { Mandar } \\
\text { in }\end{array}$ & 印尼 \\
\hline Thai & $\begin{array}{l}\text { ประเทศอินโดนีเ } \\
\text { ซีย }\end{array}$ \\
\hline
\end{tabular}

Contoh-contoh diatas menunjukkan bahwa kata yang sama dalam aksara yang berbeda dapat menghasilkan makna yang berbeda pula. Kata Indonesia apabila ditulis menggunakan aksara Rusia, Cina, dan Thai dalam sekejap akan membuyarkan makna kata Indonesia. Makna yang muncul mungkin saja malah rasa aneh dan bingung karena melihat aksara yang aneh dan tidak umum kita gunakan. Ini menunjukkan bahwa antara komponen fisik dari tanda (gambar atau suara) dengan makna didalamnya sebenarnya tidak memiliki kaitan sama sekali atau bersifat arbitrer. Keduanya memiliki hubungan karena ada konsensus masyarakat yang menyepakati bahwa tanda-tanda tertentu bermakna tertentu pula.

Tabel 2

Perbedaan Arti dalam Satu Kata di Beberapa Bahasa

\begin{tabular}{|l|l|l|l|l|}
\hline Kata & $\begin{array}{c}\text { Arti } \\
\text { dalam } \\
\text { Bahasa } \\
\text { Indone } \\
\text { sia }\end{array}$ & $\begin{array}{c}\text { Arti } \\
\text { dalam } \\
\text { Bahas } \\
\text { a } \\
\text { Sunda }\end{array}$ & $\begin{array}{c}\text { Arti } \\
\text { dalam } \\
\text { Bahas } \\
\text { a } \\
\text { Jawa }\end{array}$ & $\begin{array}{c}\text { Arti } \\
\text { dala } \\
\text { m } \\
\text { Bah } \\
\text { asa } \\
\text { Bali }\end{array}$ \\
\hline Amis & $\begin{array}{l}\text { Bau } \\
\text { amis } \\
\text { ikan }\end{array}$ & $\begin{array}{l}\text { Rasa } \\
\text { manis }\end{array}$ & $\begin{array}{l}\text { Bau } \\
\text { amis } \\
\text { ikan }\end{array}$ & - \\
\hline $\begin{array}{l}\text { Coko } \\
\mathrm{t}\end{array}$ & - & $\begin{array}{l}\text { Menga } \\
\text { mbil }\end{array}$ & $\begin{array}{l}\text { Mengg } \\
\text { igit }\end{array}$ & - \\
\hline $\begin{array}{l}\text { Geda } \\
\text { ng }\end{array}$ & - & Pepaya & Pisang & - \\
\hline $\begin{array}{l}\text { Caca } \\
\text { h }\end{array}$ & $\begin{array}{l}\text { Menghi } \\
\text { tung }\end{array}$ & - & $\begin{array}{l}\text { Memo } \\
\text { tong }\end{array}$ & - \\
\hline $\begin{array}{l}\text { Janga } \\
\mathrm{n}\end{array}$ & $\begin{array}{l}\text { Tidak } \\
\text { Boleh }\end{array}$ & - & Sayur & - \\
\hline Tiang & $\begin{array}{l}\text { Tongga } \\
\mathrm{k}\end{array}$ & Orang & Orang & Saya \\
\hline $\begin{array}{l}\text { Keny } \\
\text { ang }\end{array}$ & $\begin{array}{l}\text { Cukup } \\
\text { makan }\end{array}$ & - & - & $\begin{array}{l}\text { Erek } \\
\text { si }\end{array}$ \\
\hline
\end{tabular}

Kata yang sama dapat bermakna berbeda bagi masyarakat dalam budaya yang berbeda. Ini menunjukkan konsensus masyarakat yang berperan besar dalam 
memberikan makna sebuah tanda. Konsep tanda yang arbitrer ini kemudian akan menjadi dasar bagi konsep semiotika Saussure paling penting, yaitu pembagian tanda menjadi penanda dan petanda.

\section{B. SEGITIGA TANDA SAUSSURE}

Saussure meletakkan tanda dalam konteks komunikasi manusia dengan melakukan pemilahan antara apa yang disebut signifier (penanda) dan signified (petanda). Secara sederhana signifier adalah bunyi yang bermakna atau coretan yang bermakna (aspek material), yakni apa yang dikatakan dan apa yang ditulis atau dibaca. Sementara itu signified adalah gambaran mental, yakni pikiran atau konsep aspek mental dari bahasa. (Sobur, 2004: 125).

\section{Gambar 2}

Keterkaitan tanda menurut Saussure (Moriarty dalam Smith \& friends, 2005:

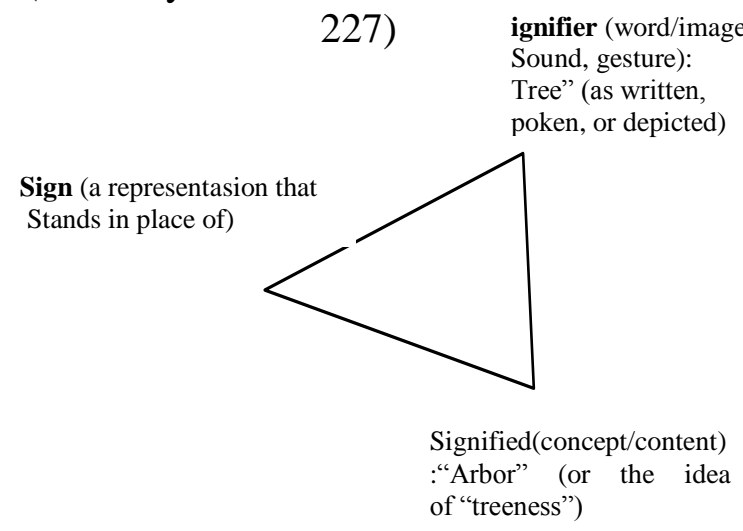

Signifier mengacu pada tampilan fisik dari sign yang dapat berupa goresan gambar, garis, warna, maupun suara atau tanda-tanda lainnya, sedangkan Signified mengacu pada makna yang tersemat pada tampilan fisik tanda tersebut. Menurut Saussure, tanda (Sign) bersifat arbitrari dimana kombinasi antara Signifier dan signified adalah entitas yang manasuka (Saussure, 1959: 67). Tidak ada hubungan

yang natural antara signifier dan signified. Tidak ada alasan intrinsik mengenai mengapa sebuah benda diberi nama sesuai dengan namanya tersebut. (Culler, 1990: 19). Setiap kata dapat menggantikan nama benda tersebut apabila telah diterima oleh konsensus atau konvensi suatu masyarakat. Bahkan menurut Saussure pada kenyataannya, setiap ekspresi yang digunakan dalam masyarakat diperoleh berdasarkan perilaku kolektif atau kesepakatan (konvensi) (Saussure, 1959: 68).

\section{Gambar 3}

\section{Anak Anjing dalam Penjabaran Segitiga Tanda Saussure}

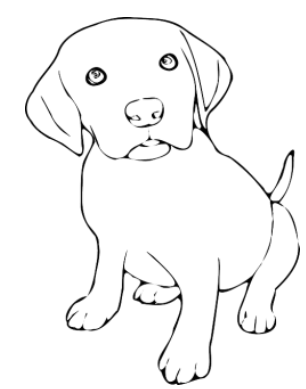

Sign

Sebuah gambar anak anjing yang lucu dan menggemaskan

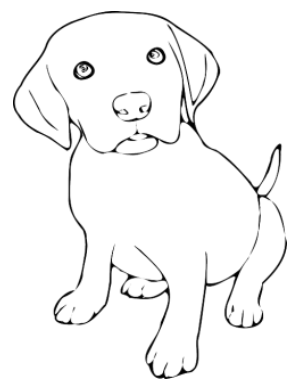

Signifier

Gambar atau goresan tinta warna hitam yang membentuk suatu gambar anak anjing
Signified

(Pemaknaan anak anjing yang lucu, menggemaskan, hangat, ceria, dan lincah) 
Hubungan yang arbitrary antara signifier dan signified juga berarti tidak ada konsep yang pasti dan universal. Kedua hal tersebut adalah entitas yang benar berbeda. (Culler, 1990: 23). Hal inilah yang menyebabkan mengapa sebuah deskripsi mengenai rumah dapat berbeda dalam pikiran orang lain, dan mengapa kata-kata dalam aksara yang berbeda dapat tidak memiliki makna sama sekali.

\section{ONOMATOPEIA}

Saussure membedakan konsep symbol dan sign. Baginya symbol tidak seluruhnya arbitrer, banyak symbol yang terkait dengan maknanya, contohnya symbol keadilan yang dilambangkan sebagai timbangan (Saussure, 1959: 68). Konsep arbriter dari sign ini sendiri tidak berlaku bagi kata-kata yang disebut sebagai Onomatopoeia dimana frasa dari sebuah signifier tampak dalam hal tertentu serupa atau imitatif (Culler, 1990: 20). Pada kasus ini signifier sangat terkait dengan signified dan hubungan diantara keduanya tidaklah arbriter. Contoh paling terlihat dari jenis kata ini adalah kata-kata suara binatang seperti "menggonggong" atau "mengeong" yang yang mengikuti suara anjing dan kucing. Contoh kata-kata onomatopoeia lain adalah:

\section{Tabel 3}

Kata-kata Onomatopeia dalam Bahasa Indonesia dan Jawa

\begin{tabular}{|l|l|l|}
\hline \multicolumn{1}{|c|}{ Kata } & Arti & \multicolumn{2}{|c|}{ Diambil Dari } \\
\hline Klik & Cocok & $\begin{array}{l}\text { Suara sambungan } \\
\text { dua benda yang } \\
\text { pas saat dipasang }\end{array}$ \\
\hline Bomb & Peledak & $\begin{array}{l}\text { Suara peledak } \\
\text { yang besar dan } \\
\text { memekakkan }\end{array}$ \\
\hline
\end{tabular}

\begin{tabular}{|l|l|l|}
\hline $\begin{array}{l}\text { Geledek } \\
\text { (Jawa) }\end{array}$ & Petir & $\begin{array}{l}\text { Suara petir yang } \\
\text { menggelegar } \\
\text { membelah udara }\end{array}$ \\
\hline $\begin{array}{l}\text { Sepur } \\
\text { (Jawa) }\end{array}$ & $\begin{array}{l}\text { Kereta } \\
\text { Api }\end{array}$ & $\begin{array}{l}\text { Suara cerobong } \\
\text { kereta api kayu }\end{array}$ \\
\hline
\end{tabular}

Meskipun banyak contoh kata-kata onomatopoeia, Saussure tetap berpendapat bahwa secara umum sign bersifat arbitrer. Menurutnya kata-kata onomatopoeic tidak pernah menjadi elemen organis dari sistem linguistic dan jumlahnya jauh lebih kecil dari yang umumnya diduga (Saussure, 1959: 69).

\section{STUDI \\ SINKRONIK/DIAKRONIK DAN LANGUE/PAROLE}

Terdapat sebuah konsekuensi penting dari konsep arbitrary dalam sign. Konsekuensi ini adalah munculnya perbedaan antara studi sinkronik dan diakronik dari bahasa. Sinkronik adalah studi mengenai system bahasa pada kondisi tertentu dengan mengabaikan waktu. Sedangkan diakronik adalah studi mengenai evolusi bahasa dalam setiap waktu. (Culler, 1990: 35). Kajian sinkronik bahasa dalam pemahaman ini hanya mencoba untuk melihat sistem dan struktur dari bahasa pada satu waktu tertentu, misalnya meneliti mengapa frasa "wanita" memiliki konotasi yang berbeda dengan "perempuan". Kajian diakronik bahasa sementara itu melihat bahasa dan makna sebagai suatu entitas yang terus berubah dan memiliki sejarah, misalnya meneliti mengenai perkembangan makna frasa "wanita" dari awal penggunaan kata tersebut hingga sekarang.

Pemahaman mengenai Sinkronik dan Diakronik ini kemudian membawa kita pada konsep langue dan parole. Langue adalah system dari bahasa dimana individu mengasimilasikan bahasa yang ia 
dengar. System gramatikal yang lahir dari lingkungan social individu tersebut. Sementara itu parole adalah kombinasi darimana individu menggunakan kode dari system bahasa untuk mengekspresikan pemikiranya. Mekanisme psiko-sosial yang membuatnya memperlihatkan kombinasi tersebut. (Culler, 1990: 29, 30).

Saussure mengeksplorasi aturan dan konvensi yang mengatur bahasa (langue) ketimbang pemakaian dan ujaran secara spesifik yang dipakai individu dalam kehidupan sehari-hari (parole). Saussure dan strukturalisme secara umum, lebih banyak menaruh perhatian kepada struktur bahasa daripada pemakaian sebenarnya. (Barker, 2000: 70). Apa yang disebut pendekatan strukturalisme dalam bahasa adalah pendekatan yang melihat hanya struktur atau sistem bahasa (sinkronik) dengan mengabaikan konteks waktu, perubahan, dan sejarahnya (diakronik). (Piliang, 2003: 256).

\section{E. ANALISIS PARADIGMATIK DAN SINTAGMATIK}

Menurut Saussure, makna dihasilkan melalui proses seleksi dan kombinasi tanda di sepanjang poros (aksis) sintagmatis dan paradigmatis. Poros sintagmatis dibangun oleh kombinasi linear antar tanda yang membentuk kalimat. Poros paradigmatik mengacu kepada arena tanda (misalnya sinonim) yang darinya segala tanda yang ada diseleksi. Makna diakumulasikan di sepanjang poros sintagmatik, sementara seleksi dari arena paradigmatik mengubah makna pada poin tertentu dalam kalimat. (Barker, 2005: 70).

\section{Gambar 4}

Aksis Sintagmatik dan Paradigmatik (Piliang, 2003: 260).

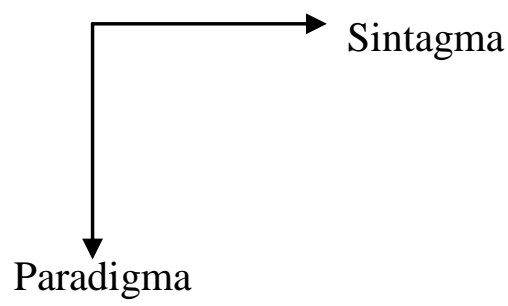

Pada gambar tersetbut diperlihatkan bahwa setiap kalimat dapat dilihat dari dua poros, Sintagma dan Paradigma. Poros paradigm tidak memiliki hubungan langsung dengan sintagma, akan tetapi perubahan-perubahan pada poros paradigma akan turut mengubah poros sintagma dari kalimat tersebut.

Tabel 4

\section{Alur Sintagmatis dan Paradigmatis} dalam sebuah Kalimat

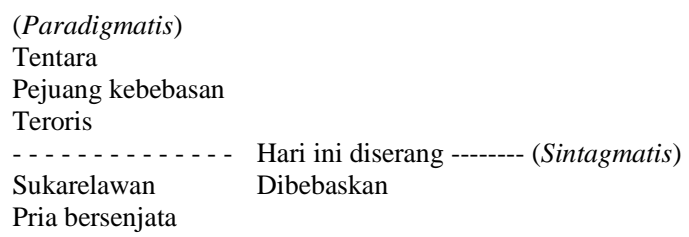

(Barker, 2005: 70)

Pada tabel tersebut terlihat bahwa pemilihan frasa-frasa tertentu dalam sebuah kalimat (paradigmatis) dapat mempengaruhi arti sintagmatis dalam kalimat tersebut. Kalimat "teroris hari ini diserang" tentunya memiliki konotasi yang lebih negatif ketimbang kalimat "pejuang kebebasan hari ini dibebaskan." 


\section{KESIMPULAN}

Berdasarkan pembahasan singkat mengenai berbagai buah pikiran Semiotika Saussure maka dapat dilihat bahwa Saussure mempercayai adanya struktur dalam bahasa. Ia lebih meyakini studi bahasa sebagai studi sinkronik yang meneliti mengenai struktur yang ada dalam bahasa, dan tidak melihat bahasa sebagai proses evolusioner yang terus berubah-ubah sepanjang sejarah. Saussure juga meyakini bahwa Parole atau bahasa tuturan manusia hanya dapat muncul karena ada Langue atau kemampuan bahasa yang bersifat kolektif. Ia meyakini bahwa ada keteraturan dalam bahasa yang dimiliki oleh setiap masyarakat. Penggunaan bahasa ini mungkin nampak berantakan dipermukaan, akan tetapi ada keteraturan yang baku didalamnya. Semiotika Strukturalisme Saussure inilah yang kemudian digunakan untuk menemukan keteraturan tersebut.

\section{DAFTAR PUSTAKA}

De Saussure, Ferdinand edited by Charles Bally and Albert Sechehaye. (1959). Course in General Linguistics $3^{\text {rd }}$ ed. New York: Philosophical Library

Barthes, Roland translated by Annette Lavers. (1972). Mythologies. New York: The Noonday Press

Sobur, Alex. (2004). Analisis Teks Media: Suatu Pengantar untuk Analisis Wacana, Analisis Semiotik, dan Analisis Framing. Bandung: Remaja Rosdakarya

Piliang, Yasraf Amir. (2003). Hipersemiotika: Tafsir Cultural Studies Atas Matinya Makna. Bandung: Jalasutra

Barker, Chris. (2005). Cultural Studies. Yogyakarta: Kreasi Wacana

Culler, Jonathan. (1990). Saussure. London: Fontana Press

Ken Smith and friends. (2005). Handbook of Visual Communication: Theory, Methods, and Media. New Jersey: Lawrence Erlbaum Associa 